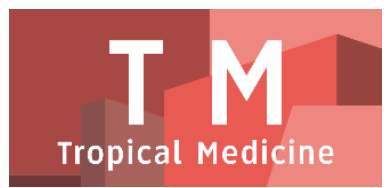

PAPER - OPEN ACCESS

\title{
Skrining Fitokimia dan Isolasi Senyawa Triterpenoid/Steroid dari Daun Buni (Antidesma Bunius (L.) Spreng.)
}

$\begin{array}{ll}\text { Author } & : \text { Gebby Elisa } \\ \text { DOI } & : 10.32734 / \text { tm.v1i1.78 }\end{array}$

Paper Page : $271-276$

Volume 1 Issue 1 - 2018 TALENTA Conference Series: Tropical Medicine (TM)

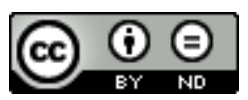

This work is licensed under a Creative Commons Attribution-NoDerivatives 4.0 International License.

Published under licence by TALENTA Publisher, Universitas Sumatera Utara
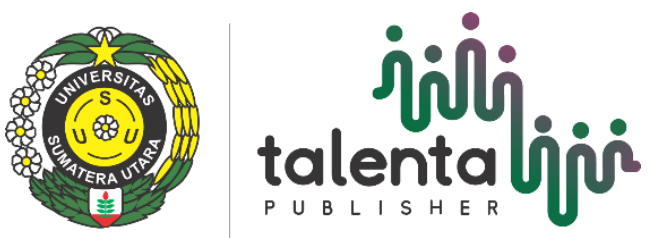


\title{
Skrining Fitokimia dan Isolasi Senyawa Triterpenoid/Steroid dari Daun Buni (Antidesma Bunius (L.) Spreng.)
}

\author{
Gebby Elisa ${ }^{\mathrm{a}}$, Marline Nainggolan ${ }^{\mathrm{a}}$, Ginda Haro ${ }^{\mathrm{a}}$ \\ ${ }^{a}$ Fakultas Farmasi, Universitas Sumatera Utara 20155, Indonesia \\ linegolan57@gmail.com
}

\begin{abstract}
Abstrak
Salah satu tumbuhan yang digunakan dalam pengobatan secara tradisional adalah buni (Antidesma bunius (L.) Spreng.), yang dapat mengobati darah tinggi, jantung berdebar cepat, anemia, sifilis, antikanker, antiradikal dan sebagai bahan pewarna alami. Daun buni mengandung sejumlah triterpenoid/steroid, saponin dan flavonoid. Senyawa triterpenoid/steroid menunjukkan aktivitas farmakologi berupa antibakteri, antiinflamasi, inhibisi terhadap sintesis kolesterol, antikanker, antitumor dan aktivitas sitotoksik terhadap sel pangkreatik.Tujuan penelitian ini untuk melakukan skrining fitokimia dan mengisolasi senyawa triterpenoid/steroid dari daun buni (Antidesma bunius (L.) Spreng.). Simplisia daun buni dilakukan skrining fitokimia kemudian diekstrasi dengan cara maserasi menggunakan pelarut $\mathrm{n}$-heksana, kemudian maserat diuapkan dengan alat penguap vakum putar. Ekstrak n-heksana yang diperoleh diisolasi dengan cara kromatografi lapis tipis (KLT) dan KLT preparatif menggunakan fase diam silika gel GF254 dan fase gerak yang sesuai. Isolat yang diperoleh diuji kemurniannya dengan KLT 2 arah dan dilanjutkan mengidentifikasi isolat dengan spektrofotometer ultraviolet dan spektrotometer inframerah.

Hasil uji skrining fitokimia diperoleh senyawa glikosida, saponin, flavonoid dan triterpenoid/steroid. Hasil KLT ekstrak n-heksan dengan fase gerak n-heksana-etilasetat (70:30) diperoleh 4 noda dengan penampak noda Liebermann-Burchard, selanjutnya ekstrak n-heksan dipisahkan dengan KLT preparatif, diperoleh 1 (satu) isolat murni berwarna merah ungu (Rf 0,90). Hasil karakterisasi isolat peroleh panjang gelombang $203,2 \mathrm{~nm}$ dan dijumpai adanya gugus hidroksil, gugus $-\mathrm{CH}$ alifatis, ikatan $\mathrm{C}=\mathrm{C}$, gugus $-\mathrm{CH} 2$ dan gugus $\mathrm{C}-\mathrm{O}$.
\end{abstract}

Kata Kunci: Antidesma bunius, skrining fitokimia, isolasi, triterpenoid/steroid;

\section{Pendahuluan}

Negara Indonesia kaya akan berbagai jenis tumbuhan dan sangat bervariasi, termasuk tumbuhan yang dapat dimanfaatkan sebagai obat. Informasi tentang nama maupun kandungan dan ramuannya belum banyak diteliti sehingga pemanfaatan tumbuhan untuk tujuan pengobatan masih banyak yang

didasarkan pada pengalaman turun-temurun (Mursito, 2001). Tanaman buni banyak ditemukan di beberapa negara Asia Tenggara, salah satu diantaranya adalah negara Indonesia. Tanaman ini di pulau

Jawa digunakan secara tradisional untuk mengobati darah tinggi, jantung berdebar cepat, anemia, sifilis

(Wijayakusuma, dkk., 1996), anti kanker (Micor, dkk., 2005), antioksidan (Butkhup dan Samappito, 
2011) dan sebagai sumber zat warna alami (Amelia, dkk., 2013). Daun buni mengandung sejumlah senyawa saponin, flavonoid, triterpen/steroid dan buahnya mengandung antosianin, flavonoid dan asam fenolat (Butkhup dan Samappito, 2008).

Tumbuhan berkhasiat obat harus dilakukan upaya untuk isolasi senyawa murni dan turunannya sebagai bahan dasar obat modern atau pembuatan ekstrak untuk obat fitofarmaka. Beberapa tahun ini, terjadi peningkatan minat pada senyawa yang berasal dari tumbuhan yang dapat diperoleh dengan berbagai yaitu isolasi dan kromatografi. Kromatografi merupakan cara untuk mengisolasi senyawa murni pada skala miligram sampai skala gram untuk telaah struktur, uji biologi, uji farmakologi, senyawa pembanding dan senyawa baku untuk penentuan kuantitatif (Hostettmann, 1995).

Berdasarkan hal diatas, maka dilakukan penelitian tentang karakterisasi simplisia, skrining fitokimia dan isolasi triterpenoid/steroid dari ekstrak n-heksana daun buni. Ekstrak n-heksana daun buni dipisahkan dengan cara kromatografi lapis tipis (KLT) dan dipisahkan dengan KLT preparatif. Isolat yang diperoleh diidentifikasi dengan spektrofotometer UV dan IR.

\section{Metode Penelitian}

\subsection{Bahan}

Sampel yang digunakan adalah daun buni (Antidesma bunius (L.) Spreng.) dan bahan kimia yang digunakan berkualitas pro analisa..

\subsection{Pengambilan Dan Preparasi Sampel}

Sampel yang digunakan dalam penelitian ini adalah daun buni yang masih segar, yang diambil dari Jalan Suwondo, Kotamadya Medan, Provinsi Sumatera Utara. Daun buni dibersihkan dari kotoran, dicuci dengan air bersih yang mengalir, ditiriskan dan dikeringaan dalam lemari pengering pada suhu $\pm 40 \mathrm{C}$, setelah kering diserbuk menggunakan blender.

\subsection{Uji Srining Fitokimia}

Uji skrining senyawa metabolit sekunder terhadap simplisia dilakukan untuk mendapatkan informasi golongan senyawa metabolit sekunder yang terdapat di dalamnya. Uji skrining daun buni hanya dilakukan pada simplisia saja.

\subsection{Prosedur Ekstrasi Simplisia}

Pembuatan ekstrak daun buni dilakukan dengan cara maserasi menggunakan pelarut $n$-heksana. Maserat yang diperoleh diuapkan menggunakan penguap vakum putar pada temperatur $\pm 40^{\circ} \mathrm{C}$ sampai diperoleh ekstrak nheksana. 


\subsection{Analisis Ekstrak n-Heksana Secara Kromatografi Lapis Tipis}

Ekstrak n-heksana di KLT dengan fase gerak n-heksana:etilasetat dengan berbagai perbandingan. Hasil analisis KLT diidentifikasi menggunakan penampak bercak Liebermann-Burchard.

\subsection{Isolasi Senyawa Triterpenoid/Steroid Secara Kromatografi Lapis Tipis Preparatif}

Ekstrak n-heksana ditotolkan pada plat pra lapis silika gel GF254 berukuran 20x20 cm yang sebelumnya telah diaktifkan, kemudian dimasukkan ke dalam chamber yang telah jenuh Plat disemprot dengan penampak bercak. Silika yang menghasilakan noda dikerok dan dielusi dengan metanol p.a. Filtrat diuapkan hingga terbentuk kristal.

\subsection{Uji Kemurnian Isolat}

Terhadap isolat yang di dapatkan dilakukan uji kemurnian dengan KLT 2 arah menggunakan fase diam plat lapis tipis GF 254 dan fase gerak I n-heksana:etilasetat (70:30) dan fase gerak II benzena:etilasetat (90:10) dengan penampak bercak Liebermann-Burchard.

\subsection{Analisis Isolat Murni Dengan Spektrofotometer Ultraviolet (UV)}

Analisis isolat murni dilakukan dengan spektrofotometer UV (Shimadzu).

\subsection{Analisis Isolat Murni Dengan Spektrofotometer Inframerah (IR)}

Analisis isolat murni dilakukan dengan menggunakan spektrofotometer FT-IR (Shimadzu).

\section{Hasil dan Pembahasan}

Hasil Uji Skrining Senyawa Kimia

Table. 1. Hasil Uji Skrining Senyawa Kimia simplisia daun buni

\begin{tabular}{|c|c|c|}
\hline No. & Nama Senyawa & Hasil (\%) \\
\hline 1. & Alkaloid & - \\
\hline 2. & Flavonoid & + \\
\hline 3. & Triterpenoid/Steroid & + \\
\hline 4. & Tanin & - \\
\hline 5. & Glikosida & + \\
\hline 6. & Saponin & + \\
\hline 7. & Glikosida antrakuinon & - \\
\hline
\end{tabular}

Keterangan : $\quad+\quad=$ mengandung golongan senyawa

$$
\text { - } \quad \text { = tidak mengandung golongan senyawa }
$$

Hasil skrining senyawa kimia pada serbuk simplisia daun buni mengandung senyawa flavonoid, saponin, glikosida dan triterpenoid/steroid. Menurut Butkhup dan Samappito (2008), daun buni mengandung sejumlah 
saponin, flavonoid dan tanin. Variasi senyawa kandungan dalam produk hasil panen tumbuhan dapat disebabkan oleh : tempat tumbuh, iklim, rekayasa agronomi dan waktu panen (Depkes RI, 2000).

\subsection{Hasil Ekstraksi}

Hasil ekstraksi menggunakan pelarut n-heksana diperoleh ekstrak sebanyak 5,05 gram.

\subsection{Hasil KLT Ekstrak n-Heksana}

Hasil KLT n-heksana daun buni didapatkan fase grak yang terbaik yaitu n-heksana:etilasetat perbandingan (70:30) menghasilkan 4 noda berwarna hijau muda, merah ungu dan hijau biru.

\subsection{Hasil KLT Preparatif}

Hasil KLT preparatif pada ekstrak n-heksana menggunakan fase diam silika gel GF 254 dan fase gerak nheksana:etilasetat (70:30) menghasilkan noda berwarna merah ungu dengan Rf 0,9.

\subsection{Hasil Uji Kemurnian}

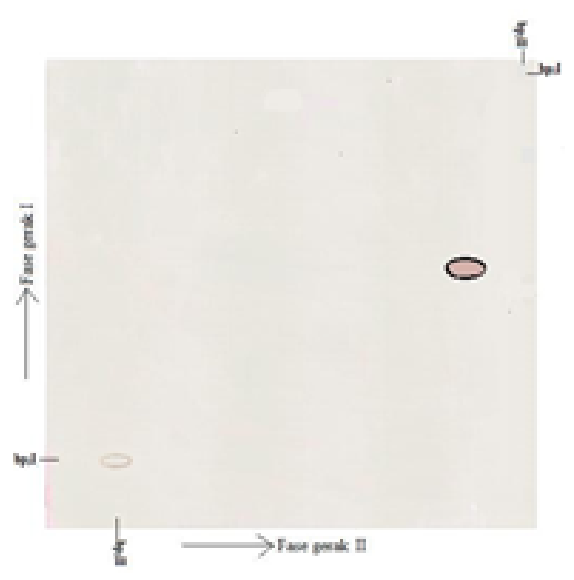

Gambar 1. Kromatogram hasil KLT 2 arah isolat 1 dengan fase gerak n-heksana-etilasetat (70:30) dan fase gerak benzena-etilasetat (90:10)

Hasil uji kemurnian dengan didapatkan 1 noda tunggal berwarna merah ungu dengan Rf sebesar 0,90.

\subsection{Hasil Identifikasi Isolat Triterpenoid/Steroid}

Terhadap isolat dilakukan pemeriksaan karakteristik dengan spektrofotometer ultraviolet (UV) dan diperoleh panjang gelombang maksimum 203,2 nm (Gambar 1.). Hasil analisis spektrofotometer inframerah (IR) adalah gugus 
$-\mathrm{OH}\left(3425,58 \mathrm{~cm}^{-1}\right)$, gugus $-\mathrm{CH}$ alifatik $\left(2920,23 \mathrm{~cm}^{-1}\right)$, ikatan $\mathrm{C}=\mathrm{C}\left(1570,06 \mathrm{~cm}^{-1}\right)$, gugus $-\mathrm{CH} 2\left(1415,75 \mathrm{~cm}^{-1}\right)$ dan gugus C-O $\left(1114,86 \mathrm{~cm}^{-1}\right)$

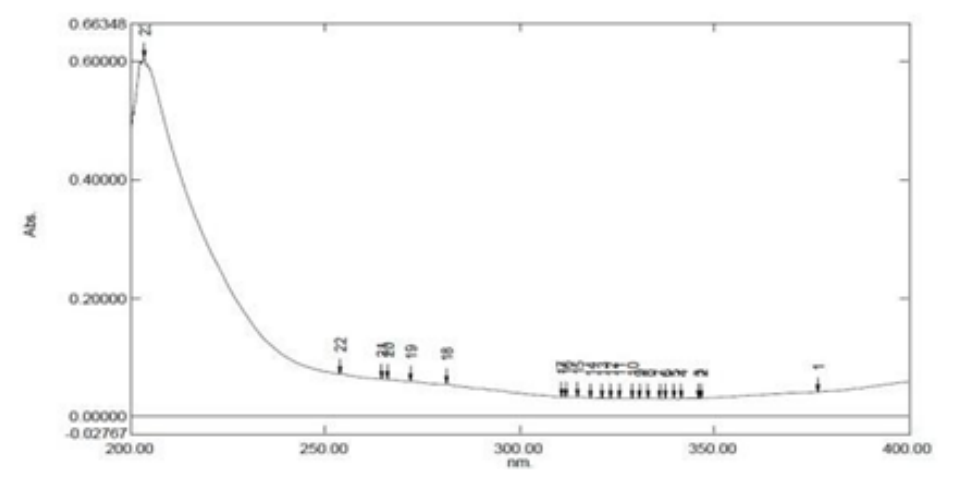

Gambar 2. Hasil identifikasi isolat 1 dengan spektrofotometer ultraviolet (UV)

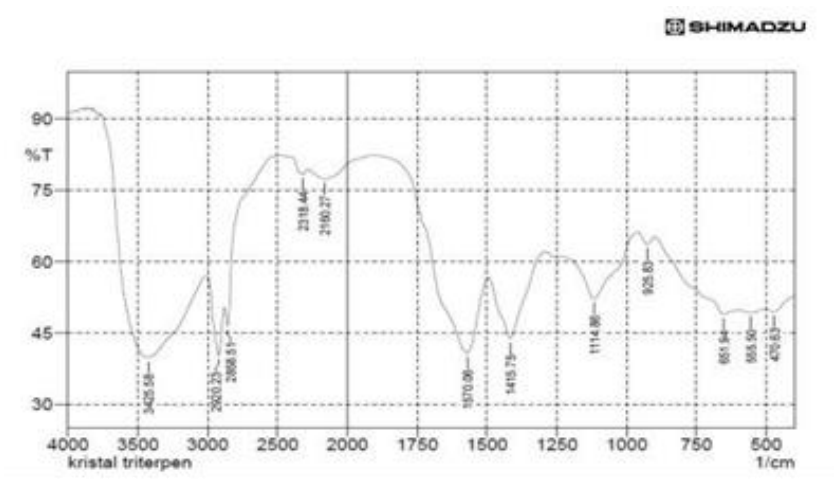

Gambar 3. Hasil identifikasi isolat 1 dengan spektrofotometer inframerah (IR)

\section{Kesimpulan}

Hasil isolasi diperoleh satu isolat berwarna merah ungu. Hasil karakterisasi isolat dengan menggunakan spektrofotometer ultraviolet (UV) dan spektrofotometer inframerah (IR) adalah absorpsi maksimum pada panjang gelombang 203,2 nm, spektrum inframerah menunjukkan adanya gugus $-\mathrm{OH}$, gugus $-\mathrm{CH}$ alifatik, ikatan $\mathrm{C}=\mathrm{C}$, gugus $-\mathrm{CH} 2$, gugus $\mathrm{C}-\mathrm{O}$.

\section{Daftar Pustaka}

[1] Butkhup, L., dan Samappito S.. 2008. Analysis on Flavonoids Contents in Mao Luang Fruits of Fifteen Cultivars (Antidesma bunius), Grown in Northeast Thailand. Pakistan Journal of Biological Sciences. 11 (7): 996-1002.

[2] Butkhup, L., dan Samappito S.. 2011. Changes In Physico-Chemical Properties, Polyphenol Compounds and Antiradical Activity During Development and Ripening of Maoluang (Antidesma bunius L. Spreng) Fruits. Journal of Fruits and Ornamental Plant Research. 19 (1): $85-$ 99.

[3] Farnsworth, N.R. (1966). Biological and Phytochemical Screening of Plant. Journal of Pharmaceutical Sciences. 55(3): $262-263$.

[4] Harborne, J.B., (1987). Metode Fitokimia. Bandung: ITB. Hal. 151-157.

[5] Depkes RI. (1995). Materia Medika Indonesia. Jilid VI. Jakarta: Departemen Kesehatan RI. Hal. 300-304, 306.

[6] Depkes RI. (1999).Cara Pengelolaan Simplisia yang Baik. Jakarta: Direktorat Jenderal Pengawas Obat dan Makanan. Departemen Kesehatan RI. Hal. 3-4.

[7] Depkes. (2000). Parameter Standar Umum Ekstrak Tumbuhan Obat. Jakarta: Departemen Kesehatan RI. Hal. 1-11. 
[8] Hostettmann, K., Hostettmann, M., dan Marston, A. (1995). Cara Kromatografi Preparatif: Penggunaan Pada Isolasi Senyawa Alam. Penerjemah: Kokasih Padmawinata. Bandung: ITB. Halaman 9-12, 33-34.

[9] Kassem, M., Hashim, A.N., dan Hassanein H.M. (2013). Bioactivity Of Antidesma bunius Leaves

[10] (Euphorbiaceae) And Their Major Phenolic Constituents. European Scientific Journal. 9 (18):217-228.

[11]Lage, H. N., Duarte, C., Coburger, A., Hilgeroth, dan Ferraira, M.J.U. (2010). Antitumor activity of terpenoids against classical and atypical multidrug resistant cancer cells.Phytomedicine. 17: 441-448.

[12] Micor, J. R. L., Deocaris, C. C., dan Mojica, E. R. E.. 2005. Biological Activity of Bignay [Antidesma bunius (L.) Spreng] Crude Extract in Artemia salina. Journal Medicine Science. 5 (3): 195-198.

[13] Mursito, B. (2001). Ramuan Tradisional Untuk Kesehatan Anak. Jakarta: Penebar Swadaya. Hal. 5.

[14] Nassar, Z., Abdalrahim., danAmin, M.S. (2010). The Pharmacological Propertis of terpenoid from Sandoricum Koetjape. Journal Medcentral. Hal 1-11.

[15]Robinson, T. (1995).Kandungan Organik Tumbuhan Tinggi. Penerjemah: Kokasih Padmawinata. Bandung: ITB. Hal. 123-157, 191.

[16] Sanchez M., Marcia,M Maria,J. V., Lucia, R.F., Gaston,S., Lydia, P., dan Jorge. A.P. (2010). Cytotoxic terpenoid from Nardophyllum bryoides. Phytochemistry. 71: 1395-1399

[17] Wijayakusuma, H.S. (1996). Tanaman Berkhasiat obat di Indonesia. Cetakan kedua. Jakarta: Pustaka Kartini. Hal. 7. 